\title{
Wenatchee Growers
}

Lynda S. Livingston, (E-mail: 1livingston@ups.edu), University of Puget Sound

\begin{abstract}
Darrel Reynolds, executive vice president of Wenatchee Growers and grandson of its founder, had been approached by owners of another family-owned fruit company about a buyout. If Darrel accepted their offer, Wenatchee would immediately expand from Washington state into California, becoming the largest producer of cherries in North America. While this would greatly lengthen Wenatchee's selling season, it would also mean new management and logistical challenges. Darrel needed to decide if the acquisition makes sense, and if so, how much to pay for his closely-held target.
\end{abstract}

\section{INTRODUCTION}

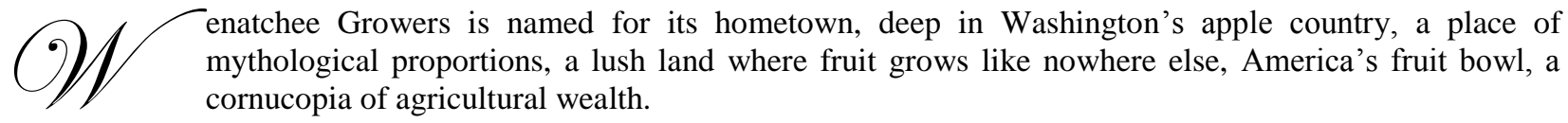

Every year, the region produces enough apples "to reach to the moon and halfway back." ${ }^{1}$ But Washington grows more than apples, and so does Wenatchee Growers. Over $60 \%$ of the apples, pears, and cherries that Washington state residents find in their produce departments come from Wenatchee Growers. Cherries, in particular, are big business for the company, since cherries are three times as profitable as apples. Cherries would be an even bigger business if Wenatchee acquired West Coast Fruit (WCF), the producer of $18 \%$ of the cherry crop from California.

Wenatchee Growers is the largest shipper of fresh sweet cherries in North America. West Coast Fruit, one of the largest cherry operations in California, has access to that state's earliest-available cherries. Together, they would guarantee their customers the availability of fresh cherries for longer than any other grower/shipper/marketer ("from shipping point to customer") in North America. Darrel Reynolds, the executive vice president of Wenatchee, had been pondering such an alliance since three of WCF's five partners approached him in early 2003, asking to be bought out. Valuing this offer was the first real challenge of Darrel's management career. He had only worked full-time in the family business for two years, since earning a business degree and becoming the first member of his family to graduate from college. His sudden rise to a key position at Wenatchee stirred up some resentment among his family members, especially among those with extensive experience in the fruit industry. Regardless, Darrel's family had entrusted him with the fate of Wenatchee Growers, and he was the driving force behind the potential merger with West Coast Fruit Company. He had to value the offer correctly.

\section{THE REYNOLDS FAMILY AND WENATCHEE GROWERS}

Wenatchee Growers was founded by Hank Reynolds, Darrel's grandfather. Hank started growing cherries in the late 1950s, but after earning only $\$ 89$ his first year, he worried that growing fruit would not allow him to support his mother, wife, and three children. During a trip to the buyers' market, Hank discovered part of his problem: his cherries were being sold there in an acidic and dehydrated state. "You have to realize that was a whole year's work for me," Hank said. "It really made me think. I wasn't about to give up or sell out, but I did start looking at new ways of doing things. I figured the only way to get good fruit to market was to pack and sell it myself."

\footnotetext{
${ }^{1}$ All of these quotes are taken from Washington Apple Country, by Rick Steigmeyer and John Marshall (Graphic Arts Cebter Publishing Portland, OR, 1995.
} 
Hank wanted to find a new way to harvest, pack, and sell his cherries so that they would arrive to market in their original quality state. Over the next three years, despite numerous difficulties and a tight budget, Hank was able to save enough money to purchase his own cherry-packing equipment and build a small warehouse - the initial inputs for Wenatchee Growers. His business plan was simple: he would "pick in the morning and pack in the afternoon." Better able to manage and control the quality of his crops, Hank finally sold his first box of cherries at the New York Growers Auction in 1962. This was the beginning of a new era for Hank. Now, more than three decades later, several of Hank's sons and his grandson Darrel ran Hank's company - the largest cherry shipper in North America.

Much of Wenatchee Growers' success could be attributed to intense quality control. They aggressively invested their profits into research and development, and were an industry leader in responsible consumer packaging and environmental practices. "We put whatever money is needed into the product, so that it will be the best in the world," said Darrel, "but we also put resources into finding a balance to keep things going for the next generation of Reynolds'." Today, the company's year-round "quality control" shipping policies benefit 350 Northwest growers, not to mention millions of consumers in the more than thirty countries that import their fruit.

Wenatchee grew pears, apricots, cherries, and apples. Every year, they produced roughly 6 million cases of apples and 2.5 million cases of cherries (about 30\% of the state's cherry crop); ten percent of this was organic. Cherries were three times more profitable than apples. During the winter, the company employed 750 workers, but during the peak growing season it employed 2,000-3,000. Wenatchee also had 250 affiliated, independent growers in Washington, California, New Zealand, and Chile, from whom they got 30-40\% of the fruit they distributed. The rest they grew themselves. Wenatchee had 5,400 acres of its own orchard land, but had regional contracts translating into 10,000 total "captive" acres. This was a significant advantage for them: orchards are the critical fixed asset for cherry production, making entry into the market difficult. Wenatchee sold its produce all over the world. They had greatly benefited from the emergence of global trade, given their positioning as a free trader. "More than 20 percent of our shipments went overseas last year," said Darrel. "We have no problem with the idea of a global economy. It has really turned out to be a win for us in places like Mexico and the Pacific Rim."

\section{Who is West Coast Fruit?}

West Coast Fruit (WCF) was started in the 1920s by two brothers from Sicily, one of whom was now 82. It had always been family-run. It was currently structured as a general partnership, with $30 \%$ owned by the general partner, $30 \%$ by one limited partner, and the remaining $40 \%$ split equally among three other limited partners. Wenatchee was offered one of the $30 \%$ stakes and two of the smaller ones. Management of the company had now passed to the third and fourth generation of the family, and Darrel says that "at generation three, the wheels fell off the tricycle." Hence the incentive for a buyout.

WCF was a vertically integrated grower, packer, and marketer of fresh sweet cherries produced in the San Joaquin Valley of California. They processed and marketed about 1 million cases every year, or about $18 \%$ of the fresh cherries grown in California. They had earned a high level of respect and an excellent strategic position in the California cherry industry during their 75 years' of cherry-packing experience. West Coast Fruit's business strategy was to deliver the earliest, highest-quality sweet cherries to the world premium markets, getting the highest prices and the highest returns for its growers.

WCF had been a consistent leader in the introduction of new processing and handling methods. They pioneered the pre-cooling, hydro-cooling, and water-flow transport processes that they used in their packing facility. These major innovations make WCF's 320,000 square foot facility completely state-of-the-art, capable of packing $40,000,18$-pound boxes of finished fruit per day and moving them from field to export in 72 hours. As part of the buyout offer, Wenatchee could buy this facility for $\$ 6.5$ million; Darrel estimated that it would cost $\$ 8$ million to build it from scratch. 


\section{The Cherry Industry}

In 2003, on average, the United States produced more than 350 million tons of tart and sweet cherries (see Exhibits 1 and 2). 78,600 tons, the equivalent of 8,730,000 18-pound cases, comes from the Northwest. The Northwest's record for the most cherries produced in a single harvest season was 2001's 97,000 tons. The 2002 crop came up 3,600 tons short of the five-year average, at 75,000 tons. (Wenatchee's experience for this period mirrored that of the state as a whole: Wenatchee produced 22,000 tons in 2001 but only 16,000 in 2002. Their revenues were unaffected, however, since the "shortage" led to higher prices.)

The biggest threat to the Washington cherry industry is eastern Washington's cold weather, which often lasts through mid- to late April. The cherry pollination process is inhibited by cold, wet, and windy weather. (For example, in Michigan, spring frosts and poor pollination have been known to destroy up to $90 \%$ of the year's cherry crops, leaving growers with little to no income.) The threat of potential losses from severe weather is completely unpredictable.

Weather is just one of the challenges facing cherry growers. (As Darrel said, "Producing cherries is like a medical triage center-it's complete chaos.") Another is the basic fragility of the fruit. For example, some cherries like the Rainier (which has a "notoriously temperamental personality") ${ }^{2}$ must be picked "early in the morning before the fruit overheats and gets too soft to handle"; they then must be picked and packed by hand because they "show every bruise from rough handling" and would reach the consumer "look[ing] as sad as overripe bananas." Typically, cherries can survive up to four weeks if kept in a plastic bag (where the oxygen level is lower) at temperatures below 32 degrees Fahrenheit. Once the cold chain is broken, however, they can survive only a week at most. The quality of distribution and storage is therefore crucial to extending the life of a cherry; the packaging methods must be state-ofthe-art. Even in the best circumstances, though, velocity remains a more important strategic consideration than price.

The cherry season varies by region, but is always short. (In fact, many of the cherry varieties we see today were developed to ripen earlier or later than older varieties, so that the cherry-buying season could be extended. ${ }^{3}$ ) For example, the California cherry season is from April 25 through the beginning of July, while the Washington cherry season begins in mid-June and continues through the end of August (see the chart on the next page). Thus, California cherries ripen before Washington's, and when the cherry season is ending in California, it is just beginning in Washington. What this means for retailers is that they must clear the shelves after the California harvest and wait for the larger Washington harvest to come in. This results in logistical challenges for growers, retailers, and consumers alike.

\section{Conventional Cherry Availability}

\begin{tabular}{|c|c|c|c|c|c|c|c|c|c|c|c|c|c|c|c|c|c|c|}
\hline \multirow{3}{*}{2003} & \multicolumn{3}{|c|}{ Key: $\quad=$ yellow } & \multicolumn{2}{|c|}{$=$ white } & \multicolumn{3}{|c|}{ = subacid yellow } & & & & & & & & & & \\
\hline & \multicolumn{2}{|c|}{ APRIL } & \multicolumn{4}{|c|}{ MAY } & \multicolumn{4}{|c|}{ JUNE } & \multicolumn{4}{|c|}{ JULY } & \multicolumn{4}{|c|}{ AUGUST } \\
\hline & \begin{tabular}{|c|} 
Week \\
18 \\
\end{tabular} & $\begin{array}{c}\text { Week } \\
19 \\
\end{array}$ & $\begin{array}{c}\text { Week } \\
20 \\
\end{array}$ & \begin{tabular}{|c} 
Week \\
21 \\
\end{tabular} & \begin{tabular}{|c} 
Week \\
22 \\
\end{tabular} & $\begin{array}{c}\text { Week } \\
23\end{array}$ & $\begin{array}{c}\text { Week } \\
24 \\
\end{array}$ & $\begin{array}{c}\text { Week } \\
25 \\
\end{array}$ & \begin{tabular}{|c} 
Week \\
26 \\
\end{tabular} & \begin{tabular}{|c} 
Week \\
27 \\
\end{tabular} & $\begin{array}{c}\text { Week } \\
28 \\
\end{array}$ & $\begin{array}{c}\text { Week } \\
29 \\
\end{array}$ & \begin{tabular}{|c} 
Week \\
30 \\
\end{tabular} & \begin{tabular}{|c} 
Week \\
31 \\
\end{tabular} & \begin{tabular}{|c} 
Week \\
32 \\
\end{tabular} & \begin{tabular}{|c|} 
Week \\
33 \\
\end{tabular} & \begin{tabular}{|c} 
Week \\
34 \\
\end{tabular} & \begin{tabular}{|c} 
Week \\
35 \\
\end{tabular} \\
\hline California & & & & & & & & & & & & & & & & & & \\
\hline dark-sweet & & & & & & & & & & & & & & & & & & \\
\hline Washington & & & & & & & & & & & & & & & & & & \\
\hline dark-sweet & & & & & & & & & & & & & & & & & & \\
\hline Washington & & & & & & & & & & & & & & & & & & \\
\hline Rainier & & & & & & & & & & & & & & & & & & \\
\hline Washington & & & & & & & & & & & & & & & & & & \\
\hline organic dark-sweet & & & & & & & & & & & & & & & & & & \\
\hline Washington & & & & & & & & & & & & & & & & & & \\
\hline organic Rainier & & & & & & & & & & & & & & & & & & \\
\hline
\end{tabular}

2 Quoted from “The Other Rainier," by Stuart Eskenazi (Seattle Times, 6/27/04).
${ }^{3}$ ibid. 


\section{Strategic Considerations}

Darrel Reynolds believed the acquisition of West Coast Fruit would create new opportunities for the joint company. He saw most of the value from this merger coming from the increase in demand that would accompany an extension of the fruit season, the opportunity to better market the crop in coordination with retailers, and the possibility of consolidating operating facilities.

"Strategically this alliance creates a mirrored philosophy of extended cherry harvest from both locations," said Darrel. A newly allied Wenatchee/West Coast Fruit would be the first to market and the last out. A seamless extension of the season would stimulate consumer demand. As it is, retailers typically lost a full week of sales between the California and Washington seasons. During this cherry hiatus, retailers must fill their empty cherry shelves with something else, only to clear the shelves again when the Washington cherries began to arrive. Consumers were never quite sure if they would find cherries in the store or not. If Wenatchee/WCF could guarantee a constant supply of cherries throughout the summer, they could get to the retailers sooner and lock up their shelf space. In late June/early July - the period that Darrel called the "peak of product"-retailers usually dedicated about 10 feet of shelf space to cherries. Until then, it was closer to 3 feet. By increasing space at an earlier date, and by offering a higher volume of product, Wenatchee could generate a better velocity of sales. Increasing velocity meant that consumers would have a better experience. Quality, availability, and regularity would build consumer demand and generate incremental sales. In Darrel's words, "Sell-through and forced distribution will allow Wenatchee to hit the ground running, creating good velocity and good demand." He saw this as "a natural step in aligning growers with retailers in a go-to-market strategy to connect with the end consumer."

Wenatchee could capitalize on the increased demand to enhance its dealings with both small and large retailers. Wenatchee would inherit the good relationships that West Coast Fruit had already established with the smaller retailers in its area. It might also gain more clout with the larger retailers. Larger growers had a higher likelihood of establishing partnerships with national grocery chains, since the chains were consolidating the number of growers from which they buy to facilitate coordination. Being larger might also give Wenatchee more control over the way the stores handle and store the fruit. Given the fragility of the fruit, improper handling could easily mean bad experiences for customers.

A combined Wenatchee/WCF wouldn't just use its size to strong-arm retailers: it would also have something unique to offer. The expansion of the cherry season meant the retailers could avoid changing displays from cherries to something else and then back again. More product could mean more momentum and more sales. Sales could be further increased since there would be new opportunities to advertise. As it was, retailers were understandably reluctant to advertise cherries around the transition period between the California and Washington seasons, since they had to coordinate from growers in both states. If Wenatchee/WCF could ensure that fruit will be available throughout the transition, retailers might be less "gun-shy" to go on ad during this period. They might also be able to take advantage of advertising among regions. Darrel said his strategic approach is partnering - coordinating merchandising and marketing with the retailers and creating relationships that allowed retailers to trust forecasted demand for Wenatchee's product. When that happened, Wenatchee could negotiate contractual pricing. Darrel's goal was to be "in bed" with the retailers, "going to market with the retailer to connect with the consumer."

In addition to improving relations with retailers and consumers, a merger with WCF might also offer Wenatchee the potential for operating consolidation. Being able to provide product from multiple locations could diversify Wenatchee's operating risks. Were Wenatchee able to utilize West Coast's advanced facility, it could put money used currently to maintain their operational facilities to other uses. Taking advantage of these opportunities means logistical challenges, however. It is a 15-hour, 931-mile drive from Wenatchee to West Coast's facility in Stockton. The price of transporting freight wass based on weight and mileage, with the standard load for a trailer of 25,000 pounds. According to an estimate from Artic Express, a transportation company specializing in refrigerated shipping, it would cost approximately $\$ 1,301.40$ for a shipment between Stockton and Wenatchee, plus a gas surcharge of $\$ 132.55$. This did not include any sort of loading costs, and it assumed there would be no detention time (time the driver has to wait) at either facility or on the road. 


\section{Valuing West Coast Fruit}

Darrel was well aware of the numerous strategic advantages of a merger with West Coast Fruit. But the impact of such a merger on his family's company — and on his reputation within it—depended on correctly translating those advantages into dollars. West Coast Fruit was a valuable company — but how valuable? To help him find out, Darrel had collected financial information about both Wenatchee Growers and on West Coast Fruit. This is presented in Exhibits 6 and 7, respectively. For financing, Darrel planned to rely heavily on internal funds; he said Wenatchee had a very low debt/equity ratio, and he wanted to keep it that way. Wenatchee's corporate finance chief had suggested that they use a $15 \%$ discount rate to evaluate WCF, a rate which Darrel said incorporates a premium "because of the risk - wind, heat, rain, frost, fog, hail — of cherries." The rate of inflation for the food industry was $1.4 \%$, while the average rate for all items is at $3.2 \%$. The marginal personal and corporate tax rate was $37 \%$. Other macroeconomic data are presented in Exhibit 5.

In the past, Wenatchee's managers had made merger and buyout decisions based on EBITDA (for example, estimating a firm's value as 4.5 times EBITDA). Cash flow and ability to service debt were also critical. Darrel's response to this particular problem? "We could have a conversation about that over 3 bottles of wine."

Darrel was convinced that a merger with West Coast would be profitable for Wenatchee. However, to give him some flexibility in case his analyses suggest otherwise, he negotiated a one-month option to opt out of the deal. Exercising this option would cost Wenatchee \$2 million.

Is a merger with West Coast Fruit a good idea for Wenatchee Growers? If so, how much should Darrel pay for $51 \%$ of West Coast's equity?

\section{APPENDIX}

Exhibit 1: Cherry Production

\section{U.S. Production of Cherries}

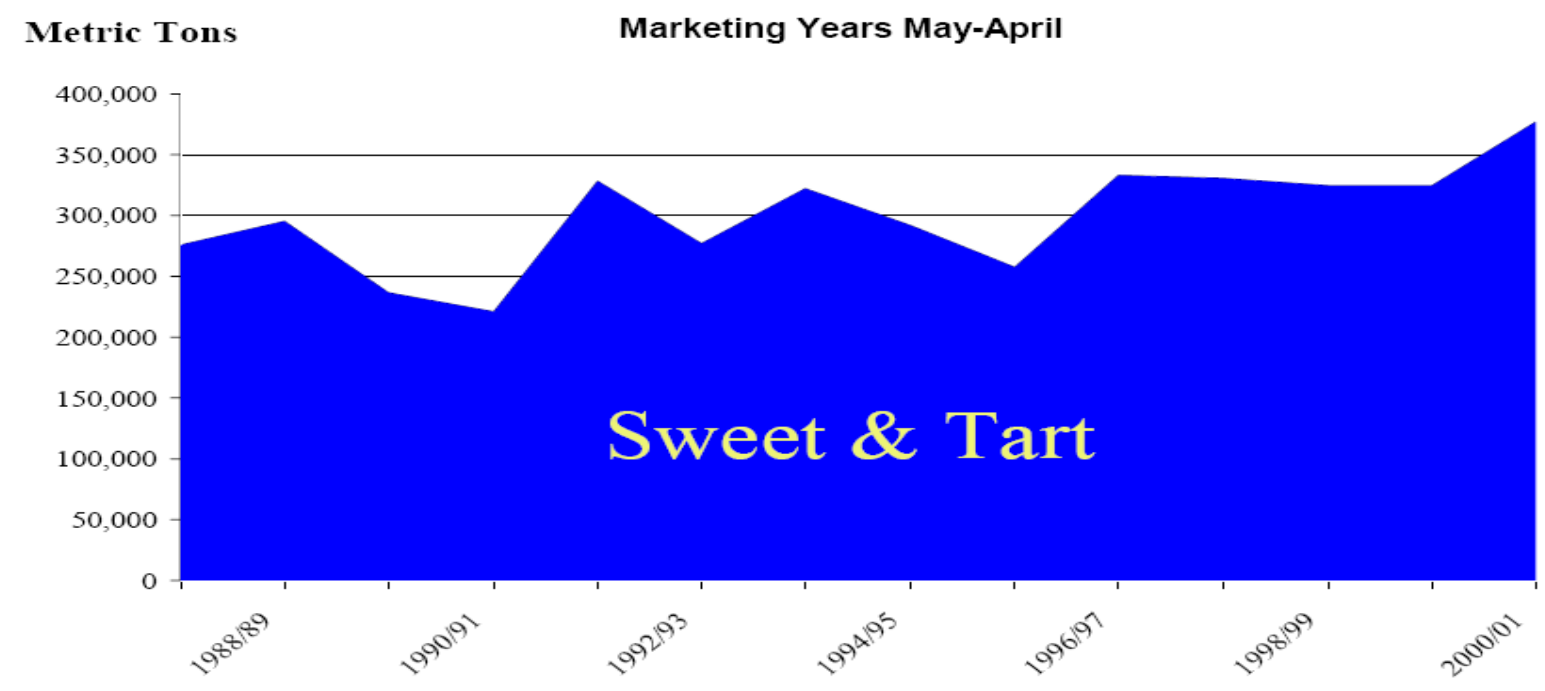

Source: USDA National Agricultural Statistics Service 
Exhibit 2: Consumption And Exports

\section{U.S. Cherry Production Climbs; While Fresh Consumption \& Processing Expands, Exports Slow}

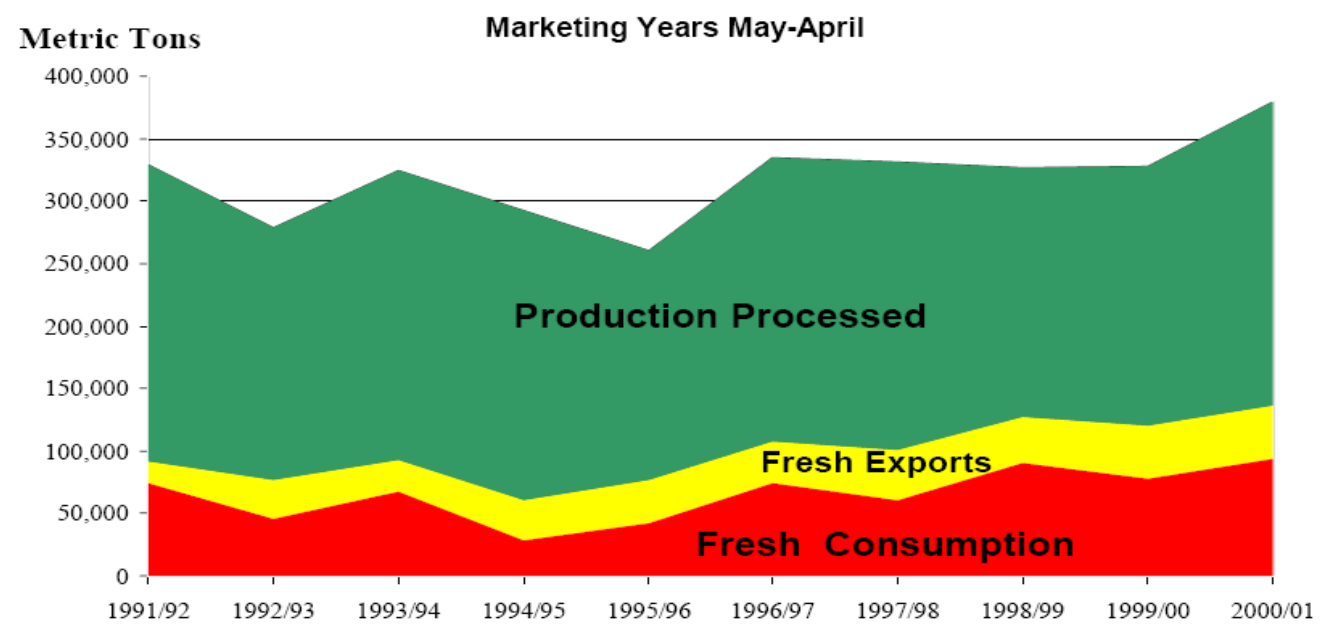

Source: USDA National Agricultural Statistics Service

Exhibit 3: Prices

\section{U.S. Fresh Cherry Prices}

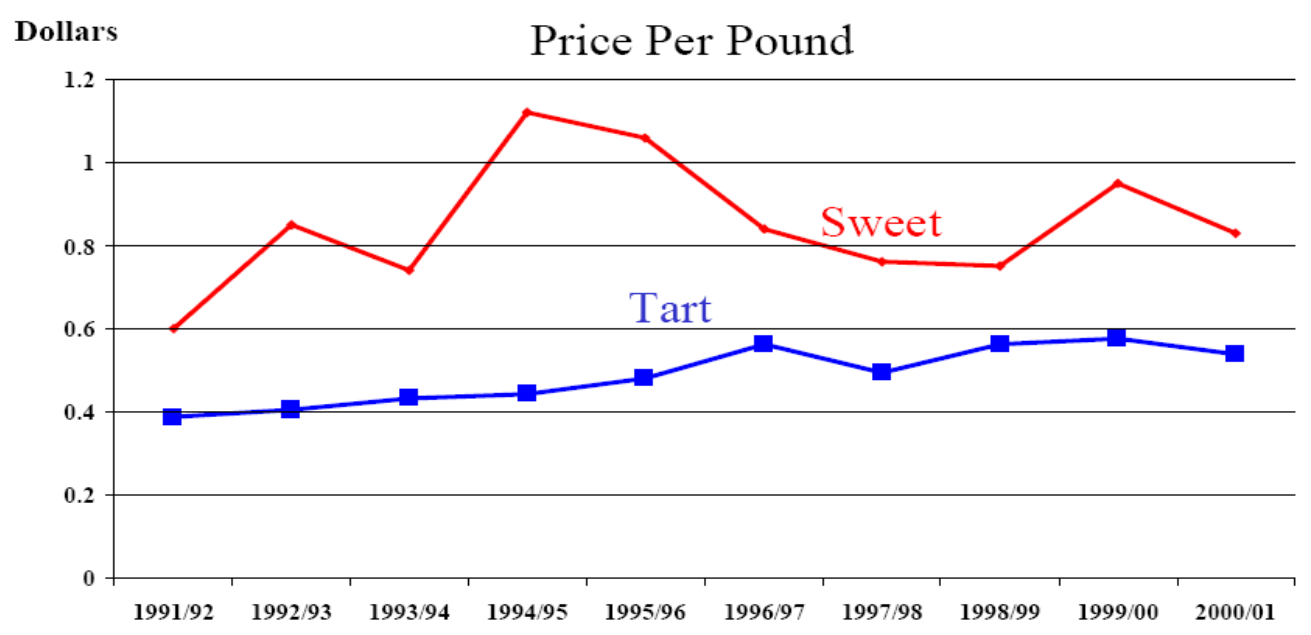

Source: USDA National Agricultural Statistics Service 


\section{Exhibit 4: Types Of Cherries}

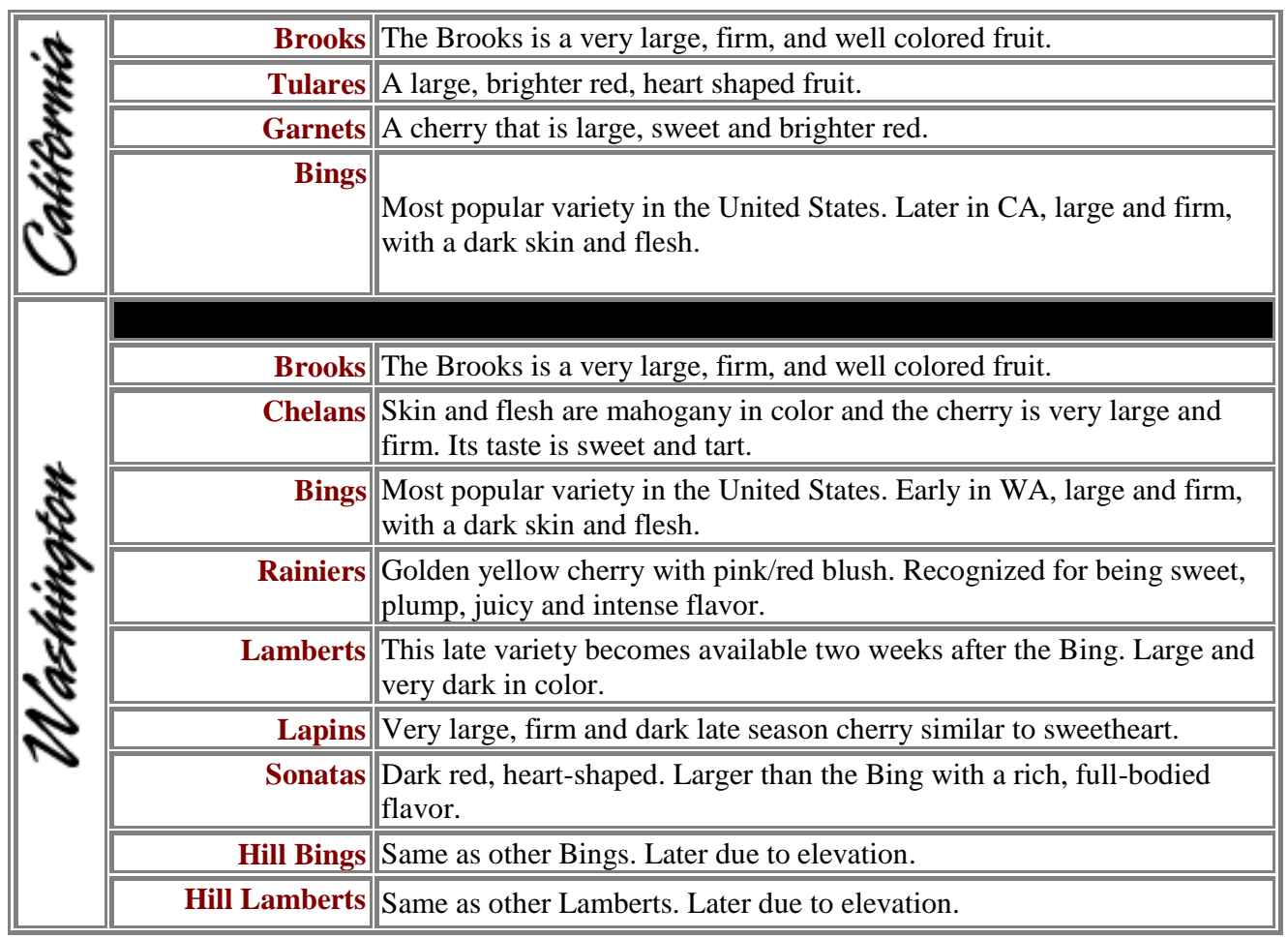

Source: company

\section{Exhibit 5: Macroeconomic Data}

\section{Prime Rate:}

The base rate on corporate loans posted by at least $75 \%$ of the nation's 30 largest banks.
Rate

$4.00 \%$
Effective Date

$06 / 27 / 02$

\section{Discount Rate:}

The charge on loans to depository institutions by the Federal

Reserve Banks.
Rate

$2.00 \%$
Effective Date

$06 / 25 / 02$

\section{Federal Funds:}

Reserves traded among commercial banks for overnight use in amounts of $\$ 1$ million or more. FOMC target rate effective 06/25/02.
Rate

$\begin{array}{ll}1.0000 \% & \text { FOMC target rate } \\ 1.0313 \% & \text { High } \\ 1.0000 \% & \text { Low } \\ 1.0000 \% & \text { Near Closing Bid } \\ 1.0313 \% & \text { Offered }\end{array}$


Treasury Yield Curve, December 2002

\begin{tabular}{|c|c|c|c|c|c|c|c|c|c|c|}
\hline date & 1-mo. & 3-mo. & 6-mo. & $1-$ & 2-yr. & 3-yr. & 5-yr. & 7-yr. & 10-yr. & 20-yr. \\
\hline $12 / 27 / 2002$ & $\overline{1.07}$ & 1.16 & $\overline{1.23}$ & $\overline{1.3}$ & $\overline{1.60}$ & 1.97 & $\overline{2.7}$ & 3.3 & 3.83 & 4.83 \\
\hline $2 / 3$ & 1.15 & 1.22 & 1.24 & 1.36 & 1.61 & 1.95 & 2.76 & 3.34 & 3.82 & 4.82 \\
\hline $2 / 31$ & 1.20 & 1.22 & 1.23 & 1.32 & 1.61 & 1.99 & 2.78 & 3.36 & 3.83 & 4.83 \\
\hline
\end{tabular}

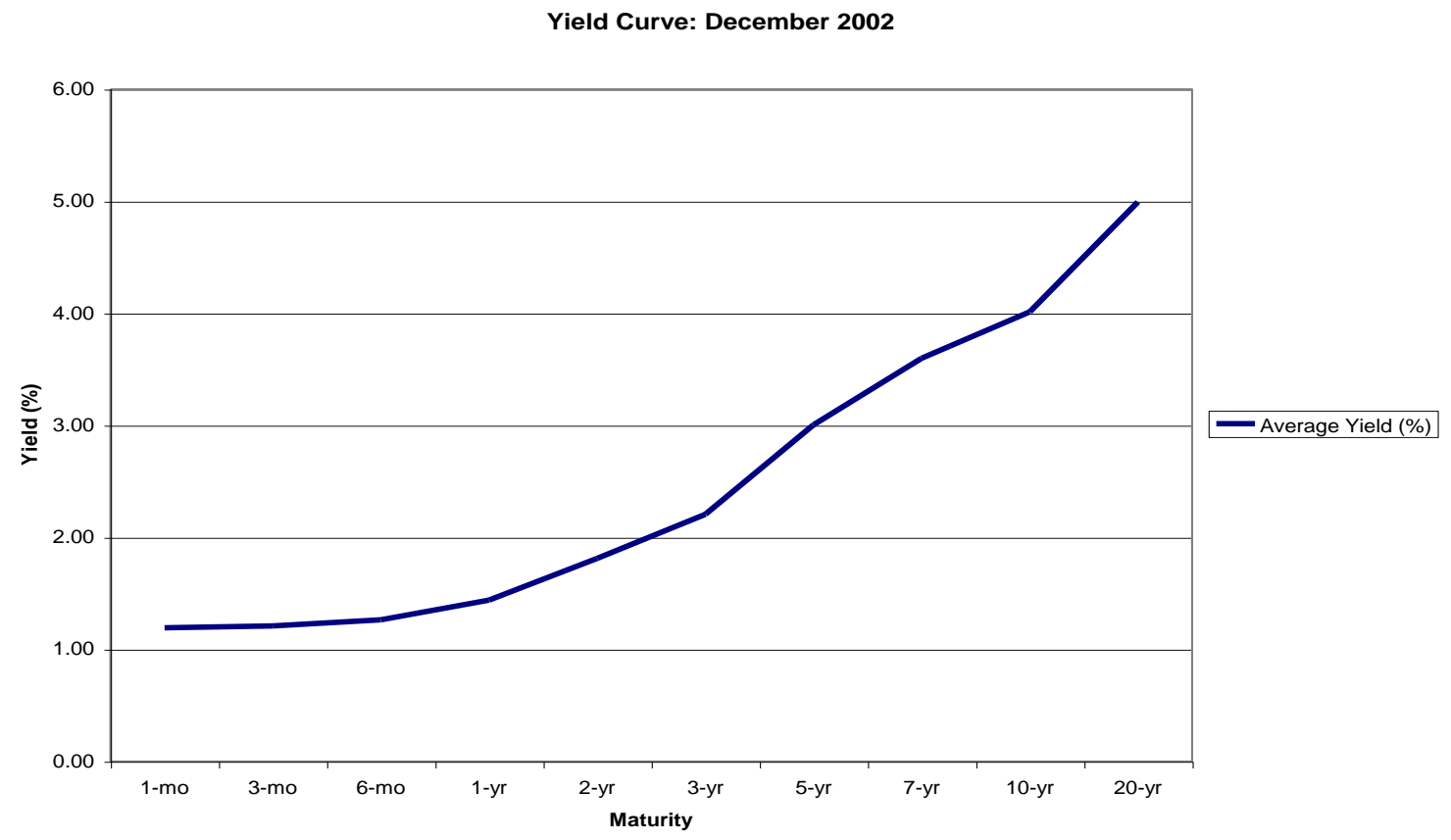

Source: Wall Street Journal 


\section{Exhibit 6: Wenatchee Growers Financial Data}

\begin{tabular}{|c|c|c|c|c|c|}
\hline \multicolumn{6}{|c|}{$\begin{array}{c}\text { Wenatchee Growers } \\
\text { Balance Sheet }\end{array}$} \\
\hline \multicolumn{4}{|c|}{ December 31, } & \multicolumn{2}{|c|}{ December 31, } \\
\hline Assets & 2002 & 2001 & Liab \& Shareholders' Equity & 2002 & 2001 \\
\hline Current Assets & & & Current Liabilities & & \\
\hline Cash and Cash Equivalents & $5,814,753$ & 496,979 & Accounts Payable & & \\
\hline Accounts Receivable & & & Trade & $5,836,069$ & $6,401,571$ \\
\hline Trade & $19,166,768$ & $17,445,173$ & Undistributed fruit proceeds & $12,845,297$ & $3,099,663$ \\
\hline Growers & $2,444,028$ & $2,608,483$ & Growers & $4,622,933$ & $5,305,794$ \\
\hline Other & 647,331 & 557,931 & Related Parties & 60,185 & 37,639 \\
\hline Related parties, curr port & $3,754,930$ & $5,375,573$ & Other & 6,883 & 627,819 \\
\hline Packing supplies inventory & $2,264,639$ & $1,999,198$ & Accrued expenses & $1,170,760$ & $1,231,653$ \\
\hline Fruit inventory & 383,221 & $2,929,565$ & Line of Credit & 0 & $4,500,000$ \\
\hline Prepaid expenses & 878,048 & 293,724 & Crop Loans & 182,731 & 344,922 \\
\hline \multirow[t]{2}{*}{ Total current assets } & $35,353,718$ & $31,706,626$ & \multirow{2}{*}{$\begin{array}{l}\text { Current portion of LT debt and } \\
\text { obligations under capital leases }\end{array}$} & & \\
\hline & & & & $5,424,123$ & $6,261,833$ \\
\hline \multicolumn{2}{|l|}{ Land, Building, \& Equipment } & & \multirow[t]{2}{*}{ Total current liabilities } & $30,148,981$ & $27,810,894$ \\
\hline Land and improvements & $6,687,767$ & $5,426,727$ & & & \\
\hline Buildings & $48,640,924$ & $47,115,100$ & LT Debt and Oblig & & \\
\hline Machinery, equip, \& furnit & $63,067,215$ & $51,956,839$ & Under Capital Leases, net of & $37,642,014$ & $33,448,834$ \\
\hline \multirow[t]{2}{*}{ Orchard development } & $2,874,875$ & $2,781,939$ & current portion & & \\
\hline & $121,270,781$ & $107,280,605$ & & & \\
\hline \multirow[t]{2}{*}{ Less accumulated deprec } & $51,221,872$ & $45,066,357$ & \multirow[t]{2}{*}{ Subordinated Debt } & $4,033,658$ & $4,033,658$ \\
\hline & $70,048,909$ & $62,214,248$ & & & \\
\hline \multirow[t]{2}{*}{ Construction in progress } & $1,180,399$ & $2,684,352$ & \multirow[t]{2}{*}{ Deferred Compensation } & 123,462 & 120,011 \\
\hline & $71,229,308$ & $64,898,600$ & & & \\
\hline Related-Party Receivables & & & Minority Interests & 444,901 & 511,501 \\
\hline \multirow[t]{2}{*}{ net of current portion } & $4,255,968$ & $3,004,547$ & & & \\
\hline & & & \multicolumn{3}{|l|}{ Stockholders' Equity } \\
\hline Other Assets & & & Common stock, $\$ 100$ par, 750 & 70,000 & 70,000 \\
\hline Investments & 555,907 & 97,277 & shares authorized, 700 shares & & \\
\hline Grower rec, net of curr port & 610,403 & & issued and outstanding & & \\
\hline \multirow[t]{6}{*}{ Other Assets } & 605,932 & 712,096 & Additional paid-in capital & 625,307 & 625,307 \\
\hline & $1,772,242$ & 809,373 & Accumulated other comprehensive & $-698,359$ & $-507,900$ \\
\hline & & & loss & & \\
\hline & $112,611,236$ & $100,419,146$ & \multirow[t]{3}{*}{ Retained earnings } & $40,221,272$ & $34,306,841$ \\
\hline & & & & $40,218,220$ & $34,494,248$ \\
\hline & & & & $112,611,236$ & $100,419,146$ \\
\hline
\end{tabular}




\section{Exhibit 6: Continued}

Wenatchee Growers, Inc.

Consolidated Statement of Income

Packing \& Warehouse Revenue

Cost of Packing \& Warehouse

Gross Profit

Selling, General, \& Administrative

Income from Operations

Other Income

$$
\begin{aligned}
& \text { Interest income } \\
& \text { Interest expense } \\
& \text { Other income, net }
\end{aligned}
$$

Income before Minority Interest

Minority Interest in Subsidiary Income

Net Income

Wenatchee Growers, Inc.

Consolidated Statement of Changes in Stockholders' Equity

Balance, December 31, 2001

Comprehensive Income

Other comprehensive income

Unrealized loss on interest rate swap Net Income

Total comprehensive income

Balance, December 31, 2002
December 31, 2002

$71,294,671$

$54,473,857$

$16,820,814$

$8,516,529$

$8,304,285$

501,040

$-3,191,991$

481,865

$-2,209,086$

$6,095,199$

$-180,768$

\begin{tabular}{|c|c|c|c|c|}
\hline & & $\begin{array}{c}\text { Accumulated } \\
\text { Other }\end{array}$ & & \\
\hline $\begin{array}{l}\text { Common } \\
\text { Stock }\end{array}$ & $\begin{array}{l}\text { Additional Paid-in } \\
\text { Capital }\end{array}$ & $\begin{array}{c}\text { Comprehensive } \\
\text { Income }\end{array}$ & $\begin{array}{l}\text { Retained } \\
\text { Earnings }\end{array}$ & Total \\
\hline 70,000 & 625,307 & $-507,900$ & $34,306,841$ & $34,494,248$ \\
\hline
\end{tabular}

$5,914,431$

December 31, 2002

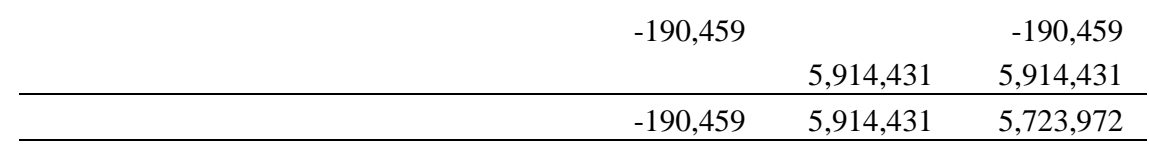

70,000

625,307

$-698,359 \quad 40,221,272 \quad 40,218,220$ 


\section{Exhibit 6: Continued}

Wenatchee Growers, Inc.

Consolidated Statement of Cash Flows

Year Ended December 31, 2002

\section{Net Cash from Operating Activities}

Net Income

$5,914,431$

Adjustments to reconcile net income

to net cash from operating activities

Depreciation \& Amortization

$6,071,178$

Minority Interest in subsidiary income

180,768

Income from investments

$-258,524$

Allowance from doubtful accounts

298,565

Increase (decrease) in cash due to

changes in assets and liabilities

\section{Accounts receivable \\ Inventory \\ Prepaid Expenses \\ Grower Receivable \\ Other Assets \\ Accounts payable \\ Accrued expenses \\ Accrued interest \\ Deferred compensation}

Net Cash from Operations

\section{Cash Flows from Investing Activities}

Loans issuance costs

Purchases of land, buildings, and equip

Net repayments on related-party receivables

Net Cash from investing activities

Cash Flows from Financing Activities

Proceeds from crop loans

Payments made on crop loans

Net payments made on line-of-credit facility

Payments made on long-term debt

Additional borrowings on long-term debt

Capital distributions to LLC member

Net Cash from financing activities

Net Increase in Cash and Cash Equivalents

Cash and Cash Equivalents, December 31, 2001

Cash and Cash Equivalents, December 31, 2002
$-30,140$

$-4,452,973$

369,222

$-4,113,891$

997,835

$-1,160,026$

$-4,500,000$

$-15,482,141$

$10,613,902$

$-247,368$

$-9,777,798$

$5,317,774$

496,979

$5,814,753$ 


\section{Exhibit 6: Completed}

Supplemental disclosure of cash flows information:

- Interest received in cash during the year

$\$ 501,040$

- Interest paid in cash during the year

$3,275,193$

Schedule of noncash investing and financing activities:

- $\quad$ During the year ended December 31, 2002, the Company had an unrealized loss on interest rate swaps of $\$ 190,459$. The effect of this is an increase in long-term debt of $\$ 190,459$ and a decrease in other comprehensive income of $\$ 190,459$.

- $\quad$ As of December 31, 2002 and 2001, the Company had capitalized, as prepaid expenses, \$432,033 and $\$ 302,647$, respectively, of depreciation expense associated with cherry packing equipment.

- $\quad$ During the year ended December 31, 2002, the Company exchanged \$200,106 of grower receivable balances into ownership of two orchard investments.

- $\quad$ During the year ended December 31, 2002, the Company entered into fixed asset capital leases for $\$ 8,033,250$.

Exhibit 7: West Coast Fruit Financial Data

\begin{tabular}{|c|c|c|c|}
\hline & BOX & POUNDS & \\
\hline variable income & $\overline{\$ 14.06}$ & $\$ 0.59$ & $\$ 12,104,697$ \\
\hline fixed income & 0.00 & 0.00 & $\$ 2,537$ \\
\hline total income & 14.06 & 0.59 & $\$ 12,107,234$ \\
\hline variable labor & 3.69 & 0.16 & $\$ 3,180,399$ \\
\hline variable operating costs & 4.21 & 0.18 & $\$ 3,621,102$ \\
\hline total VC & 7.90 & 0.34 & $\$ 6,801,501$ \\
\hline fixed labor & 0.84 & 0.04 & $\$ 726,844$ \\
\hline interest cost & 0.39 & 0.02 & $\$ 331,607$ \\
\hline fixed costs & 3.33 & 0.14 & $\$ 2,868,452$ \\
\hline total FC & 4.56 & 0.20 & $\$ 3,926,903$ \\
\hline total costs & 12.46 & 0.54 & $\$ 10,728,404$ \\
\hline net income & 1.60 & 0.05 & $\$ 1,378,830$ \\
\hline contribution margin & 6.16 & 0.26 & \\
\hline break even & 637,058 & $15,072,914$ & \\
\hline
\end{tabular}

\section{Additional Information:}

1. West Coast Fruit (WCF) uses a line of credit to meet its seasonal working capital needs. It may borrow up to a total of $\$ 5,000,000$ between January and August. The minimum initial draw is $\$ 300,000$. Interest is paid at the end of the month on the balance outstanding at the beginning of the month, at a stated rate of $4.5 \%$. 
When the firm generates available cash flow, it is first applied to any outstanding balance from this line. All borrowings must be repaid by October 1 .

2. Cherry production projections for WCF:

$\begin{array}{cc}\text { MONTH } & \text { \# of boxes } \\ \text { APRIL } & 42,377 \\ \text { MAY } & 450,950 \\ \text { JUN } & 403,399 \\ \text { JULY } & 8,327\end{array}$

3. Most of WCF's sales are made on account, charged and paid during the harvest cycle (April through July). There are also approximately $\$ 3.5$ million in cash sales during these months, made in proportion to the number of boxes produced.

4. Between April and July, WCF makes cash payments to its growers of approximately $\$ 3$ million. These are also made in proportion to production.

5. WCF's fixed administrative payroll is $\$ 28,730$. In January and August, inventory, maintenance, and accounting statement preparation cause this portion of payroll to 4 and 5 times normal, respectively. February and March also require extra labor inputs, as WCF gears up for harvest. Total administrative payroll is 1.5 times normal in these two months.

6. Variable labor charges for harvest labor is determined as $\$ 3.69 /$ box produced.

7. WCF's bookkeeper has prepared some basic pro-forma monthly balance sheets for 2003. These are shown on the next page. However, he did not adjust the current liabilities to reflect payments of the current portion of long-term debt; changes in total current liabilities reflect only payments on trade accounts payable. Required debt payments are shown in the table below.

8. WCF leases certain portions of CJL Orchards. The lease calls for varying monthly payments, corresponding to the harvest cycle. Required payments are listed in the table below.

\begin{tabular}{|c|c|c|}
\hline MONTH & $\begin{array}{c}\text { REQUIRED } \\
\text { PAYMENTS ON } \\
\text { LONG-TERM DEBT } \\
\end{array}$ & $\begin{array}{l}\text { ORCHARD } \\
\text { PAYMENTS } \\
\end{array}$ \\
\hline JAN & $\$ \$ 58,177$ & 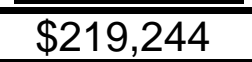 \\
\hline FEB & $\$ 51,358$ & $\$ 30,000$ \\
\hline MAR & $\$ 44,400$ & $\$ 30,000$ \\
\hline APR & $\$ 51,611$ & $\$ 60,000$ \\
\hline MAY & $\$ 44,500$ & $\$ 100,000$ \\
\hline JUN & $\$ 44,500$ & $\$ 100,000$ \\
\hline JUL & $\$ 51,867$ & $\$ 100,000$ \\
\hline AUG & $\$ 44,600$ & $\$ 30,000$ \\
\hline SEP & $\$ 44,700$ & $\$ 30,000$ \\
\hline OCT & $\$ 64,285$ & $\$ 30,000$ \\
\hline NOV & $\$ 45,100$ & $\$ 30,000$ \\
\hline DEC & $\$ 44,800$ & $\$ 30,000$ \\
\hline
\end{tabular}

9. Rent for WCF's office space is $\$ 55,000 /$ month.

10. WCF's owners' capital draws total $\$ 33,000 /$ month.

11. WCF's long-term debt carries a stated rate of $6 \%$. 


\section{APPENDIX}

\section{Summary}

Wenatchee Growers, a third-generation family firm based in Wenatchee, Washington, was considering the acquisition of West Coast Fruit Company (WCF) of California. Three of the five family members who control WCF were ready to divest themselves of their shares, and had approached the managers of Wenatchee with an offer to buy $51 \%$ of WCF's equity. The challenge for Wenatchee (and the students) was to determine the value of that equity stake.

\section{Target Courses/Intended Audience}

This case was partially written by students in a senior-level advanced corporate finance course, and was designed to be used in future sections of that course. The case addresses many of the salient issues of corporate finance, including estimating the opportunity cost of capital and the required return on equity; adjusting betas and/or discount rates for varying capital structures; deciphering financial statements and using ratio analysis; projecting project cash flows; and estimating the benefits of a merger. However, the significant strategic elements of the case make it equally appropriate for a capstone strategy course.

\section{Suggested Questions}

1. How should Wenatchee evaluate the potential acquisition of WCF?

2. How should Wenatchee determine the appropriate discount rate to use to value WCF's cash flows?

3. What is the value of WCF as a stand-alone business? How should this value affect Wenatchee's assessment of the potential acquisition?

4. What is the value of Wenatchee Growers as a stand-alone business?

5. What are the significant strategic elements that Wenatchee must consider when evaluating the potential acquisition?

6. How much should Wenatchee pay for $51 \%$ of WCF's equity?

\section{EPILOGUE}

Wenatchee did buy West Coast Fruit, for about $\$ 10$ million. Wenatchee's finance chief had valued the WCF at between $\$ 10-\$ 12$ million, using the discount rate of $15 \%$ and an average annual cash flow of about $\$ 2.25$ million. In 2003, cherry sales were up in the market as a whole by almost $40 \%$.

\section{BIBLIOGRAPHY}

1. Brealey, Richard A., Stewart C. Myers, and Franklin Allen, Principles of Corporate Finance, $8^{\text {th }}$ ed., McGraw-Hill/Irwin, Boston, MA, 2006.

2. Eskenazi, Stuart, The Other Rainier: The Making and Marketing of Washington's Celebrity Fruit, Seattle Times, 6/27/04.

3. Grinblatt, Mark and Sheridan Titman, Financial Markets and Corporate Strategy, Irwin/McGraw-Hill, Boston, MA, 1998.

4. Lewellen, Wilbur G. and Michael G. Ferri, Strategies for the Merger Game: Management and the Market, Financial Management, Winter 1983.

5. Litwin, Stuart M., The Merger and Acquisition Process: A Primer on Getting the Deal Done, The Financier ACMT, Vol. 2, No. 4, November 1995.

6. Marshall, John and Rick Steigmeyer, Washington Apple Country, Graphic Arts Center Publishing, Portland, OR, 1995.

7. Peers, Martin and Robin Sidel, Days May Be Numbered for EBITDA Numbers, Wall Street Journal, 7/3/02.

8. Villalonga, Belen and Raphael Amit, How Do Family Ownership, Control, and Management Affect Firm Value? working paper, 9/20/04.

9. Weaver, Samuel C., Robert S. Harris, Daniel W. Bielinski, and Kenneth F. MacKenzie, Merger and Acquisition Analysis, Financial Management, Summer 1991.

NOTE: This case is based on real events. The financial statements and other information presented are based on the actual numbers used by the participants (although some scaling may have been applied and other adjustments may have been made for clarity of exposition). The data was collected using plant visits and phone and e-mail communications. The first version of this case was written by students in an advanced corporate finance course at the University of Puget Sound. 


\begin{tabular}{|c|c|c|c|c|c|c|c|}
\hline \multirow[b]{3}{*}{ ASSETS } & \multicolumn{7}{|c|}{$\begin{array}{c}\text { WEST COAST FRUIT } \\
\text { Pro-Forma Balance Sheets: } 2003\end{array}$} \\
\hline & Dec-02 & $\underline{\text { Jan-03 }}$ & Feb-03 & Mar-03 & Apr-03 & May-03 & Jun-03 \\
\hline & \\
\hline total cash & $\$ 90,508$ & $\$ 102,595$ & $\$ 0$ & $\$ 0$ & $\$ 0$ & $\$ 0$ & $\$ 4,618,618$ \\
\hline$A / R$ fruit sales & $\$ 95,651$ & $\$ 251,386$ & $\$ 88,788$ & $\$ 1,236$ & $\$ 738,336$ & $\$ 8,641,128$ & $\$ 7,895,543$ \\
\hline total other $A / R$ & $\$ 1,223,121$ & $\$ 1,224,181$ & $\$ 1,224,181$ & $\$ 1,224,181$ & $\$ 1,224,181$ & $\$ 1,224,181$ & $\$ 1,224,181$ \\
\hline total other current assets & $\$ 756,039$ & $\$ 756,039$ & $\$ 756,039$ & $\$ 756,039$ & $\$ 756,039$ & $\$ 756,039$ & $\$ 756,039$ \\
\hline total PP\&E & $\$ 5,817,769$ & $\$ 6,003,563$ & $\$ 5,999,163$ & $\$ 5,994,763$ & $\$ 6,020,363$ & $\$ 6,085,963$ & $\$ 6,151,563$ \\
\hline total loans receivable & $\$ 240,945$ & $\$ 773,364$ & $\$ 973,364$ & $\$ 973,364$ & $\$ 973,364$ & $\$ 973,364$ & $\$ 973,364$ \\
\hline TOTAL ASSETS & $\$ 8,224,033$ & $\$ 9,111,128$ & $\$ 9,041,535$ & $\$ 8,949,583$ & $\$ 9,712,283$ & $\$ 17,680,675$ & $\$ 21,619,308$ \\
\hline \multicolumn{8}{|l|}{ LIABILITIES } \\
\hline$\overline{\text { total current liabilities }}$ & $\$ 989,491$ & $\$ 1,792,545$ & $\$ 2,032,163$ & $\$ 2,365,759$ & $\$ 3,236,374$ & $\$ 8,363,797$ & $\$ 10,647,768$ \\
\hline total long-term debt & $\$ 2,812,555$ & $\$ 2,754,438$ & $\$ 2,703,080$ & $\$ 2,658,680$ & $\$ 2,607,069$ & $\$ 2,562,569$ & $\$ 2,518,069$ \\
\hline total liabilities & $\$ 3,806,200$ & $\$ 4,251,779$ & $\$ 4,646,682$ & $\$ 5,124,439$ & $\$ 5,586,756$ & $\$ 5,053,022$ & $\$ 4,489,494$ \\
\hline total stockholders' equity & $\$ 4,417,833$ & $\$ 4,859,349$ & $\$ 4,394,853$ & $\$ 3,825,144$ & $\$ 4,125,527$ & $\$ 12,627,653$ & $\$ 17,129,814$ \\
\hline TOTAL L\&OE & $\$ 8,224,033$ & $\$ 9,111,128$ & $\$ 9,041,535$ & $\overline{\$ 8,949,583}$ & $\overline{\$ 9,712,283}$ & $\$ 17,680,675$ & $\overline{\$ 21,619,308}$ \\
\hline
\end{tabular}




\begin{tabular}{|c|c|c|c|c|c|c|}
\hline \multirow[b]{3}{*}{ ASSETS } & \multicolumn{6}{|c|}{$\begin{array}{c}\text { WEST COAST FRUIT } \\
\text { Pro-Forma Balance Sheets: } 2003\end{array}$} \\
\hline & Jul-03 & Aug-03 & $\underline{\text { Sep-03 }}$ & $\underline{\text { Oct-03 }}$ & Nov-03 & Dec-03 \\
\hline & \\
\hline total cash & $\$ 8,833,204$ & $\$ 1,250,381$ & $\$ 1,162,922$ & $\$ 842,177$ & $\$ 576,897$ & $\$ 309,132$ \\
\hline$A / R$ fruit sales & $\$ 1,699,983$ & $\$ 340,985$ & $\$ 1,236$ & $\$ 1,236$ & $\$ 1,236$ & $\$ 1,236$ \\
\hline total other $A / R$ & $\$ 1,224,181$ & $\$ 1,224,181$ & $\$ 1,224,181$ & $\$ 1,224,181$ & $\$ 1,224,181$ & $\$ 1,224,181$ \\
\hline total other current assets & $\$ 756,039$ & $\$ 756,039$ & $\$ 756,039$ & $\$ 756,039$ & $\$ 756,039$ & $\$ 756,039$ \\
\hline total PP\&E & $\$ 6,217,163$ & $\$ 6,212,763$ & $\$ 6,208,363$ & $\$ 6,203,963$ & $\$ 6,199,563$ & $\$ 6,195,163$ \\
\hline total loans receivable & $\$ 973,364$ & $\$ 973,364$ & $\$ 973,364$ & $\$ 973,364$ & $\$ 973,364$ & $\$ 973,364$ \\
\hline TOTAL ASSETS & $\$ 19,703,934$ & $\$ 10,757,713$ & $\$ 10,326,105$ & $\$ 10,000,960$ & $\$ 9,731,280$ & $\$ 9,459,115$ \\
\hline \multicolumn{7}{|l|}{ 니ABILITIES } \\
\hline total current liabilities & $\$ 9,913,292$ & $\$ 1,360,557$ & $\$ 1,217,899$ & $\$ 1,160,634$ & $\$ 1,140,388$ & $\$ 1,141,726$ \\
\hline total long-term debt & $\$ 2,466,202$ & $\$ 2,421,602$ & $\$ 2,376,902$ & $\$ 2,312,617$ & $\$ 2,267,517$ & $\$ 2,222,717$ \\
\hline total liabilities & $\$ 4,203,151$ & $\$ 3,782,159$ & $\$ 3,594,801$ & $\$ 3,473,251$ & $\$ 3,407,905$ & $\$ 3,364,443$ \\
\hline total stockholders' & $\$ 15,500,783$ & $\$ 6,975,554$ & $\$ 6,731,304$ & $\$ 6,527,709$ & $\$ 6,323,375$ & $\$ 6,094,672$ \\
\hline TOTAL L\&OE & $\$ 19,703,934$ & $\$ 10,757,713$ & $\$ 10,326,105$ & $\$ 10,000,960$ & $\$ 9,731,280$ & $\$ 9,459,115$ \\
\hline
\end{tabular}


Journal of Business Case Studies - Second Quarter 2007

Volume 3, Number 2 